\title{
W stronę chirurgii zarodka: Socjoprawne aspekty innowacyjnych technik wspomaganego rozrodu ${ }^{1}$
}

\author{
Błażej Kmieciak (Uniwersytet Medyczny w Łodzi)
}

\section{Wprowadzenie}

Na początku lipca 2013r. rozpoczął się w Polsce obowiązywanie: Program zdrowotny leczenia niepłodności metodą in vitro (Ministerstwo Zdrowia 2013). Pomimo pojawiających się wątpliwości prawnych oraz medycznych dotyczących zasad przyjętych w przywołanym dokumencie, Ministerstwo Zdrowia zdecydowało się na uruchomieniu wspomnianego programu, który, w trakcie trzyletniego obowiązywania, ma dotyczyć 15 tys. par. W tle powyższych działań pojawiła się informacja, zgodnie z którą rząd Wielkiej Brytanii udzielił poparcia naukowcom podejmującym próby zmierzające do opanowania nowatorskiej metody wspomaganego rozrodu, w ramach której wykorzystywane mają być nie jedna, a dwie żeńskie komórki jałowe. Założeniem tej techniki jest stworzenie zarodka, który nie odziedziczy po matce wadliwego mitochondrialnym DNA (mtDNA). Jak relacjonowały media, w ramach proponowanych działań wykorzystywana będzie dodatkowa żeńska gameta pochodząca od anonimowej dawczyni. Ponadto wskazywano, że podobna technika stanowi propozycję interwencji medycznej, która zmniejsza do minimum prawdopodobieństwo występowania poważnych wad rozwojowych, jakie dostrzegane są $\mathrm{u}$ zarodków powstałych $\mathrm{z}$ połączenia plemnika z komórką jajową z uszkodzonym mtDNA. W podobnych materiałach dodawano ponadto, że stosowanie $\mathrm{w}$ laboratoriach tego typu procedur umożliwia naukowcom skorzystanie $\mathrm{z}$ narzędzi pozwalających walczyć $\mathrm{z}$ niebezpiecznymi chorobami o mitochondrialnym podłożu (Kossobudzka 2012)

Na początku lutego 2015r. brytyjski parlament ostatecznie wyraził zgodę na wykorzystywanie omawianej techniki w procedurze wspomaganego rozrodu (Ricki 2015). Przeciwnicy promowania omawianego typu interwencji medycznych zwracali oraz nadal zwracają uwagę, że działania te to $\mathrm{w}$ istocie "równia pochyła", która prowadzi do produkcji człowieka na zamówienie.

\footnotetext{
${ }^{1}$ Projekt sfinansowany ze środków Narodowego Centrum Nauki przyznanych na podstawie decyzji numer DEC-2013/10/E/HS5/00157.

W pracy wykorzystano materiały zebrane przez autora w trakcie prac nad artykułami: Od poczęcia dziecka z trojgiem rodziców do narodzin chirurgii zarodka oraz O jeden rodzic za daleko, opublikowanych na stronie biotechnologia.pl
} 
Wskazywano, że proponowane genetyczne zabiegi, nieuchronnie prowadzą do pojawienia się inżynierii eugenicznej. Ich efektem może być eliminacja ze społeczeństwa osób obarczonych wadami, zaburzeniami oraz chorobami, diagnozowanymi na najwcześniejszym etapie rozwoju człowieka (Szymanowski 2013, 2).

Zapoznając się z treścią podobnych debat warto zwrócić uwagę, że nie wystąpił się $\mathrm{w}$ nich istotny wątek, który dostrzec można w toku analizy zjawiska społecznego, jakim jest zapłodnienie pozaustrojowe. Oceniając bowiem zaproponowane przez badaczy w ostatnim czasie metody modyfikacji mtDNA komórki jajowej wykorzystywanej w procedurze in vitro, dojść można do wniosku, iż jesteśmy obecnie świadkami powstawania nowej "subdyscypliny" medycznej, którą określić możemy mianem mikrochirurgii prenatalnej. Dziedzina ta stanowić może uzupełnienie technik określanych mianem diagnostyki preimplantacyjnej (ang. PGD—pre-implantation genetic diagnosis lub franc. DPI-diagnostic préimplantatoire), wykorzystywanej w celu oceny zdolności rozwojowych zarodka (PAN 2012, 1).

W tym miejscu jednak zasadnym jest by rozważyć, czy podobne działania stanowią cenną innowacyjną zmianę, czy też prawdą jest, że ich zakres prowadzić może do niepokojących oraz niebezpiecznych konsekwencji? Czy pojawienie się „chirurgii” zarodka jest tym samym zjawiskiem pozytywnym, czy też negatywnym? Być może podobne formy działań klinicznych stanowić mogą realną szansę na pełne wykorzystanie możliwości, jakie daje diagnostyka preimplantacyjna? Jak jednak z perspektywy prawnorodzinnej ocenić „stwarzanie” zarodków posiadających de facto trójkę rodziców?

\section{Proponowana metoda analizy}

Próba odpowiedzi na powyżej postawione pytania zostanie podjęta po przez analizę wypowiedzi medialnych, jakie odnosiły się do problematyki modyfikacji mtDNA komórki jajowej (Zob. Goban-Klas 1984, 294). Omawianej w tym miejscu analizie zostaną poddane przede wszystkim materiały, które znalazły się na portalach internetowych, informujących o wspomnianych działaniach naukowców oraz ich akceptacji wyrażonej przez rząd Wielkiej Brytanii. Tym samym ukazane oraz omówione zostaną przede wszystkim opinie ekspertów odnoszące się do wspomnianej problematyki. Podobne zawężenie zagadnienia pozwoli uniknąć błędu w postaci ogólnikowości oraz zbyt szerokiego ujęcia tematu badawczego. Stąd też w badaniu pomocne będą archiwa m. in. mediów, takich, jak: Dział Nauka dziennika „Gazeta Wyborcza”, materiały Działu Bioetyka portalu Biotechnologia.pl oraz publikacje serwisu biomedical.pl. Jak się okazuje coraz częściej to właśnie media internetowe, jako pierwsze reagują na kluczowe odkrycia, jakie pojawiają się np. w medycynie. Uzasadnionym wydaje się zatem odniesienie do wypowiedzi 
prezentowanych m. in. w przywołanych redakcjach branżowych (Lisowska-Magdziarz 2006, 3). W pracy wykorzystana zostanie również metoda analizy dokumentów, w tym zwłaszcza: sprawozdań, programów oraz ustaw odnoszących się do poruszanej problematyki (Pieniążek, Stefaniuk 2003, 138). Głównym celem podjętych działań będzie ukazanie argumentów prezentowanych przez zwolenników oraz przeciwników podejmowania podobnych interwencji na ludzkim zarodku. Stąd też podstawowymi jednostkami proponowanej analizy będą: słowa (wypowiedzi ekspertów) oraz pełne przepisy wskazanych dokumentów prawnych (Zob. Szczepaniak 2012, 91). W celu podsumowania oraz próby odpowiedzi na postawione powyżej pytania wykorzystana zostanie wtórna analiza danych zawartych w raportach omar materiałach badawczych (Szacka 2003, 40-48). Do oceny etycznej opisywanych poniżej działań biotechnologicznych wykorzystana zostanie metoda tzw. Wnioskowania moralnego autorstwa Arnolda Goldsteina (Morawski 2003, 60-61). Pomocą w powyższych działaniach służyć będą zapisy kodeksu etycznego diagnosty laboratoryjnego (Kodeks 2006, 6-8).

\section{Przekaz - treść}

Pierwsze informacje medialne dotyczące modyfikacji mtDNA komórki jajowej pojawiły się w połowie 2012r. Wówczas to zwrócono uwagę, że naukowcy z Narodowego Centrum Badań nad Naczelnymi stanu Oregon $\mathrm{w}$ Beaverton (USA) odnieśli pierwsze sukcesy $\mathrm{w}$ omawianej materii. Zatrudnieni $\mathrm{w}$ nim naukowcy dokonali połączenia dwóch komórek jajowych, a ściślej mówiąc zdrowego mtDNA jednej komórki, ze zdrowym jądrem komórkowym drugiej komórki jajowej. W wyniku powyższego pojawiła się techniczna możliwość „ominięcia” problemu związanego ze stwierdzonymi wadami w obszarze mitochondrium komórki, które w przyszłości mogą wpływać na pojawienie się poważnych zaburzeń rozwojowych (Stepniewska 2012). W krótkim czasie po upublicznieniu ww. informacji, serwisy medialne powróciły do powyższego tematu informując, że rząd Wielkiej Brytanii poparł przywołaną metodę biotechnologiczną, jednocześnie podejmując pierwsze kroki w celu wprowadzenia prawnych możliwości uruchomienia nowatorskiego programu in vitro już w 2015r. (Ordo Iuris 2013). Cześć brytyjskich bioetyków poparła przywołaną metodę jednocześnie wzywając do dalszych prac sprawdzających bezpieczeństwo jej stosowania. Innego zdania była jednak Szkocka Rada Bioetyki Człowieka (SCHB), która zgodnie z doniesieniami The Telegraph „orzekła, że powoływanie do istnienia dzieci o trojgu rodziców genetycznych jest sprzeczne z prawem międzynarodowym" (Kobisz 2013, 2).

Z kolei przedstawiciele organizacji Human Genetics Alert dodawali, że metoda ta jest całkowicie niepotrzebna. Podobnymi opiniami osoby te dołączają do grupy badaczy uznających, iż modyfikacja mtDNA to w istocie 
akceptacja neoeugeniki oraz wprowadzenie prawnych możliwości produkcji ludzi (Human Life International 2013).

Działania te jednak nie zmieniły nastawienia zgodnie, z którym w Wielkiej Brytanii dąży się by podobne działania prokreacyjne stanowiły alternatywną propozycję dla par starających się o dziecko. Szacuje się, ze w Anglii obecnie żyje ok. 12 tys. osób dotkniętych zaburzeniami o mitochondrialnych przyczynach. Mitochondria to $\mathrm{w}$ istocie małe fabryki energetyczne komórek. Warto dodać, że to właśnie w ich obszarze powstaje większość adenozynotrifosforanu (ATP), a wiec związku będącego źródłem energii dla przemian komórkowych. Zaburzenia w tym obszarze prowadzić mogą w przyszłości do schorzeń związanych $\mathrm{z}$ nieprawidłowym napięciem mięśni szczególnie wrażliwych na niedobory energetyczne: ślepota, problemy kardiologiczne, nieprawidłowe napięcie (miopatie, neuropatie i encefalopatie). Szacuje się, iż choroby wywołane wadliwymi mitochondriami występują raz na 6,5 tys. Porodów (Zob. Wojewoda, Zabłocki, Szczepanowska 2011).

$\mathrm{Na}$ wyspach brytyjskich pierwsze badania nad wykorzystaniem zdrowego mtDNA $w$ procedurze In vitro podjęte zostały w 2008r. W chwili obecnej wspomina się w tym temacie o dwóch głównych technikach. Jak donosił już w 2012r. serwis Biomedical: „naukowcy najpierw przeprowadzają zapłodnienie komórki jajowej przez plemnik, a następnie pobierają ten materiał genetyczny i zaimplantują go do drugiej komórki jajowej. W ten sposób płód będzie miał 0,1\% jej materiału genetycznego" (Biomedical 2012). W tym wypadku mowa jest o zapłodnieniu jednej komórki jajowej. Badacze donoszą jednak, że w procedurze brane jest również pod uwagę jednoczesne zapłodnienie dwóch komórek jajowych, zarówno tej ze zdrowym, jak i zaburzanym mtDNA (Biomedical 2012).

Należy wskazać, że dziecko poczęte w powyżej opisany sposób odziedziczy w znacznej większości informację genetyczną zapewnioną ze strony plemnika ojca oraz komórki jajowej mamy (zob. Leźnicki, Lewandowska 2013, 120-121). W opinii badaczy dziecko nie odziedziczy ze strony „drugiej” matki, kluczowych cech odnoszących się do tożsamości dziecka oraz jego relacji z rodzicami. Na indywidualne cechy nie będzie miało zatem wpływu mtDNA odziedziczone po dawczyni. W opinii prof. Sally Davies, naczelnej lekarz Anglii nie możemy w tym miejscu mówić, że dawczyni staje się trzecim rodzicem z racji na minimalną ilość materiału genetycznego, jakie dziecko po niej odziedziczy. Jak dodaje przywołana badaczka: „Zamierzamy wprowadzić tę terapię tak szybko, jak to możliwe. Choroby mitochondrialne mają dla wielu rodzin katastrofalne skutki. Kobiety, które się z nimi borykają, żyją w świadomości, że przekażą je dzieciom ... "niemal na pewno" dawczyni mitochondrium pozostałaby anonimowa. Sugerowałoby to, że nie będzie mieć żadnych praw do dziecka" (Czarnecki 2013).

Analizująca podobne wypowiedzi pojawia się jednak istotna wątpliwość: Ile bowiem genów wystarczy by powiedzieć, że dawca jest ojcem 
lub matką danego osobnika? Czy jeśli dwoje rodziców przekaże dziecku od 10 do 20 tys. genów, a dawczyni jedynie kilkadziesiąt, czy wówczas możemy ją w pewnym sensie genetycznie oraz prawnie „wydziedziczy”? Jak kobietę tą zatem nazwać? Jak określić fragment genetyczny człowieka, który będzie obcy jego biologicznym rodzicom?

Dr David King, dyrektor przywołanego już Human Genetics Alert uznaje, że promowanie przywołanej metody to „decyzja, która prowadzi do przekroczenia pewnej linii i tworzenia rynku eugenicznego, na którym będzie można zamawiać dzieci o pewnych cechach, została podjęta na podstawie całkowicie tendencyjnych i niewystarczających konsultacji” (Bruchwald 2013). Choć podobne opinie krytyczne wyrażone przez ekspertów posiadają kluczowe znaczenie w debacie, warto jednak rozważyć, czy w chwili obecnej nie obserwujemy jednak istotnego przełomu dotyczącego możliwości podjęcia działań terapeutycznych na ludzkim zarodku. Być może człowiek potrafi już nie tylko diagnozować problemy z ludzkim DNA? Być może wyżej opisane doniesienia to $\mathrm{w}$ istocie informacja $\mathrm{o}$ wprowadzeniu skutecznych genetycznych procedur chirurgicznych?

Cytowana już w pracy prof. Sally Davies w jednym z wywiadów, w którym wyjaśniała znaczenie promowania omawianej metody zwróciła uwagę, że w jej ocenie jest ona „procedurą ratującą życie od samego początku” (Portal Pch24 2013). Na podobną wartą etycznej analizy perspektywę zwrócili uwagę uczestnicy spotkania pt. Etyka $w$ biotechnologii i biobiznesie, jakie miało miejsce w Uniejowie w 2012r. Wskazano wówczas, że rozwój medycyny w chwili obecnej pozwala, by rozważyć zasadność podjęcia wobec zarodka określonych działań terapeutycznych. Tym samym pewne techniki modyfikujące informację genetyczną miałyby na celu zlikwidowanie choroby oraz zaobserwowanej niepełnosprawności „małego człowieka” (Kmieciak 2012, 19). Podobna metoda odwoływała by się do filozofii chirurgii płodowej, a więc operacji na dziecku wykonywanych w chwili, gdy znajduje się ono jeszcze $\mathrm{w}$ łonie matki. $\mathrm{W}$ podobnym ujęciu terapeutycznym, wychodzi się $\mathrm{z}$ założenia, w którym płód określany jest mianem pacjenta- to bowiem na nim podejmowane są konkretne, celowane działania diagnostyczne oraz terapeutyczne (Ministerstwo Zdrowia 2009, 2) Niezwykłą perspektywę podobnych działań opisuje historia Samuela Armasa, który będąc w łonie matki został poddany operacji w chwili, której miał zaledwie 21 tygodni. Historia obecnego 15-latka jest o tyle istotna, iż dotyczy przypadku, w którym to lekarze doradzali rodzicom dziecka dokonanie aborcji w związku ze zdiagnozowaniem u niego rozszczepem kręgosłupa, co uprawnia do przeprowadzenia aborcji nie tylko na terenie USA, ale również i Polski. Na aborcję nie wyrazili jednak zgody rodzice dziecka i przy wsparciu dra Josepha. Brunera z Uniwersyteckiego Centrum Medycznego Vanderbilt, w Nashville, w Tennessee zdecydowali się na poddanie matki, a przede wszystkim dziecka operacji chirurgicznej. Wspomniana operacja przeszła do historii medycyny z 
racji na fakt, iż w jej trakcie mały Samuel złapał lekarza za palec - sytuacja ta została sfotografowana (Kalb 2003, 48). Pojawienie się możliwości modyfikacji mtDNA powoduje, iż zasadnym jest rozważenie podobnych możliwości terapeutycznych do etapu zarodkowego. Aktualnie bowiem zdiagnozowanie mutacji DNA w obszarze mitochondriów pozwala na przeprowadzenie mikrooperacji, skutkującej eliminacją istotnej wady genetycznej mogącej powodować wystąpienie w przyszłości wad zagrażających życiu człowieka.

$\mathrm{Na}$ powyższy temat wypowiedział się $\mathrm{w}$ trakcie rozmowy $\mathrm{z}$ portalem biotechnologia.pl, ks. prof. Jan Wolski. Wspomniany naukowiec jest członkiem m. in. komisji bioetycznej przy Centrum Zdrowia Matki Polki w Łodzi, które specjalizuje się $w$ przeprowadzaniu operacji na dziecku przed jego narodzeniem. W trakcie wywiadu poproszono eksperta o próbę odpowiedzenia na pytanie: „Czy wspomniany postęp medyczny nie sprawi, że $\mathrm{z}$ czasem metoda ta (mowa o diagnostyce preimplantacyjnej - przyp. BK) stanie się szansa do wprowadzenia swoistej chirurgii zarodka?" Ks. prof. Wolski stwierdził:

Jeśli uzasadnimy, że niegodziwym jest cały proces in vitro, to odnosi się on do różnych jego etapów czy elementów. ... Jestem przekonany, że tutaj argument ekonomiczny będzie przewodnią motywacją i prostą kalkulacją, co bardziej będzie się opłacać: dokonać skomplikowanej chirurgii zarodkowej obarczonej $\mathrm{z}$ pewnością wielkim ryzykiem jej skuteczności, czy obrać łatwiejszą drogą zgładzenia człowieka w jego zarodkowym etapie rozwoju. Diagnostyka płodu jest godziwa, jeśli jej celem są względy terapeutyczne mającego przyjść na świat dziecka, a czasem wręcz ratowania jego życia. W przypadku diagnostyki preimplantacyjnej trudno uznać jej etyczne uzasadnienie, skoro celem nie jest przeprowadzenie terapii, a jeśli nawet taki cel byłby możliwy, to ze względu na niegodziwość całej procedury in vitro, nie jest zasadne debatowanie czy jego pewien element jest etycznie dopuszczalnym (Kmieciak 2012,12).

Powyżej przedstawiona refleksja w pełni odwołuje się do argumentacji wskazującej, iż wszelkie działania dotyczące sztucznej prokreacji posiadają charakter niemoralny (Leźnicki \& Lewandowska 2013, 124). Być może jednak pojawienia się możliwości transplantacji zdrowego mtDNA powoduje, iż metoda diagnostyki preimplantacyjnej staje się używając języka ks. Wolskiego, „bardziej godziwa”? Być moze podejmowanie podobnych działań, mając na względzie bezpieczeństwo biorących w nich udział zarodków nie posiada negatywnego charakteru? (zob. Tachibana, Amato, Sparman et al. 2012, 205).

\section{Perspektywa prawna}

Pojawienie się możliwości poczęcia dziecka, które z perspektywy biologicznej posiadać będzie $\mathrm{w}$ istocie trójkę rodziców spowodowało również podjęcie 
debaty poprzez przedstawicieli nauk prawnych. W Polsce głos w tej sprawie zajęli m. in. specjaliści z Instytutu na Rzecz Kultury Prawnej Ordo Iuris. Jest to polska organizacja ekspercka podejmująca stale działania na rzecz budowania kultury prawnej. Pracujący w niej prawnicy interweniują m. in. w sytuacjach, w których to dostrzegają, iż dochodzi do naruszenia podstawowych praw człowieka, "chcą (oni) angażować się w obronie tradycyjnego ładu społecznego oraz świata wartości, w których jest on zakorzeniony. [chcą] by prawo służyło ludziom i ich rodzinom, a nie społecznej inżynierii“ - o czym sami informują na stronie internetowej Centrum (Ordo Iuris 2015). W działaniach wspomnianego think tanku tematy bioetyczne zajmują jedno $\mathrm{z}$ czołowych miejsc. To właśnie wspomniana organizacja podjęła się analizy treści deklaracji wyrażonej przez członków Zgromadzenia Parlamentarnego Rady Europy (nr 557) odnoszących się do brytyjskiego pomysłu zalegalizowania możliwości powoływania do życia za pomocą metody in vitro dzieci posiadających w istocie trójkę rodziców (Zob. HFaEA 2013, 33). Jak wskazali eksperci Instytutu Ordo Iuris „Członkowie Zgromadzenia Parlamentarnego Rady Europy w Deklaracji 557 podkreślili, że planowana w Zjednoczonym Królestwie, oficjalna „:zgoda na tworzenie embrionów ludzkich przy użyciu materiału genetycznego pochodzącego od trójki rodziców, jest praktyką eugeniczną i jako taka zadaje gwałt godność człowieka łamiąc jednocześnie normy prawa międzynarodowego" (Ordo Iuris 2013). Polscy prawnicy przywołali ponadto kluczowe zdanie, jakie zawarte zostało w treści ww. Deklaracji. Zwrócono w nim uwagę, że „stworzenie zarodka ludzkiego z materiału genetycznego pochodzącego od więcej niż dwóch osobników ..., narusza godność człowieka i prawo międzynarodowe" (Ambroziak 2013). Prof. Aleksander Stepkowski- kierujący pracami ww. Instytutu - analizując omawiany protest części parlamentarzystów Rady Europy zwrócił uwagę, iż podjęcie działań mających na celu podobną modyfikację genetyczną posiada w istocie znamiona neoeugeniki:

Anglicy usiłują upowszechnić praktykę pozwalającą na tworzenie embrionów ludzkich z materiału genetycznego pochodzącego od trzech osób, co określić można, jako fabrykowanie dziecka pochodzącego od trojga rodziców. Uzasadnia się to chęcią eliminacji pewnych schorzeń uwarunkowanych genetycznie. Chodzi jednak o bardzo rzadkie przypadki, co do których też nie ma pewności, że będą mogły być skutecznie wyeliminowane, ponieważ większość chorób uwarunkowanych DNA mitochondrialnym jest również częściowo uwarunkowane DNA znajdującym się w jądrze komórkowym (Ambroziak 2013).

- konkludował wspomniany ekspert.

W omawianych dyskusjach zasadnym jest by wskazać na aspekt prawny dotyczący konsekwencji stosowania omawianej innowacyjnej metody wspomaganego rozrodu. Bazując $w$ tym miejscu na polskich zapisach 
prawnych warto podjąć próbę ukazania legalnych aspektów podejmowania podobnych praktyk.

W pierwszym bowiem rzędzie nie można odmówić słuszności krytycznym opiniom wyrażanym przez część badaczy oraz m. in. polskich ekspertów zgromadzonych w Instytucie Ordo Iuris. Legalny kontekst omawianej problematyki odnosi się bowiem przede wszystkim do zagadnienia tożsamości danej osoby. Debata związana $\mathrm{z}$ wykorzystaniem materiału genetycznego pochodzącego od trzech osób kieruje nas w stronę pytania: czy dziecko będzie miało zagwarantowane prawo do pełni informacji na temat swojego pochodzenia? W tym miejscu należy dodać, że zarówno zapisy aktów międzynarodowych, jak i m. in. obowiązująca w Polsce Ustawa o Rzeczniku Praw Dziecka jednoznacznie wypowiadają się na temat istoty prawa dziecka do własnej tożsamości. Pierwszy z dokumentów w art. 8 stanowi, że: „1. Państwa-Strony podejmują działania mające na celu poszanowanie prawa dziecka do zachowania jego tożsamości, w tym obywatelstwa, nazwiska, stosunków rodzinnych, zgodnych $\mathrm{z}$ prawem, z wyłączeniem bezprawnych ingerencji." Warto w tym miejscu dodać, że przepis ten został doprecyzowany ustępem drugim, w którym zobowiązano Państwa- Strony do działań mających na celu przywrócenie „bezprawnie pozbawione(j)( części lub wszystkich elementów swojej" (Konwencja 1989). W tym miejscu warto przypomnieć wypowiedź prof. Sally Davies, naczelnego lekarza Wielkiej Brytanii, która zwróciła uwagę, że „«niemal na pewno» dawczyni mitochondrium pozostałaby anonimowa" (Kossabudzka 2012). Gdyby podobna sytuacja zaistniała na terenie Polski w sposób wyraźny mogłaby ona naruszać prawo dziecka do wychowania $\mathrm{w}$ rodzinie. W podobnej sytuacji osoba poczęta, a następnie urodzona, nie miałaby pełnej możliwości do poznania tożsamości własnych rodziców (Zob. Jaros 2013, 93-97). Także z perspektywy polskiego prawa rodzinnego podobna sytuacja posiadać może wręcz paradoksalny charakter. W myśl bowiem art. Art. 61[9]. Kodeksu Rodzinnego i Opiekuńczego „Matką dziecka jest kobieta, która je urodziła" (Kodeks 1964). Przyjmując zatem, iż proponowane przez angielskich badaczy praktyki podjęte zostałyby na terenie Polski dojść można do wniosku, iż powodowałyby sytuację, w której to kobieta rodziłaby dziecko, które $\mathrm{z}$ perspektywy biologicznej posiadałoby trzech rodziców. W kontekście prawnym kobieta je rodząca posiadałaby prawo, by nazywać siebie matką. Kontekst biologiczny problemu sugerowałby, aby zwrócić uwagę, że matką dziecka jest także kobieta, która anonimowo oddała komórkę jajową do kliniki in vitro. Przekazała ona bowiem materiał, którego wykorzystanie istotnie wpłynęło na możliwość zrealizowania procedury poczęcia. Powyższą sytuację warto jednak przedstawić również w oparciu o zapisy prawa medycznego. Jako przykład można w tym miejscu podać polskie ustawodawstwo odnoszące się do powyższej materii.

Jak powyżej wspomniano podjęcie działań modyfikujących mtDNA powoduje, iż zasadnym jest wskazanie, ze zarodek w istocie znajduje się w 
sytuacji pacjenta. W polskiej ustawie o prawach pacjenta i Rzeczniku Praw Pacjenta, wskazano, że przez termin „pacjent” należy rozumieć „osobę zwracającą się o udzielenie świadczeń zdrowotnych lub korzystającą ze świadczeń zdrowotnych udzielanych przez podmiot udzielający świadczeń zdrowotnych lub osobę wykonującą zawód medyczny" (Ustawa 2008). Jak wyżej wskazano, wobec zarodka, w omawianej procedurze podejmowane są działania medyczne. We wspomnianej ustawie zwrócona została ponadto uwaga $\mathrm{w}$ art. 6. Ust.1., iż „Pacjent ma prawo do świadczeń zdrowotnych odpowiadających wymaganiom aktualnej wiedzy medycznej". Nie ulega najmniejszej wątpliwości, że metoda wspomaganego rozrodu za pomocą technik in vitro - bez względu na nadal trwające dyspucie bioetyczne określić można mianem działań w pełni odzwierciedlających aktualny stan wiedzy ginekologicznej dotyczącej wsparcia w zakresie niwelowania problemu niepłodności. Jak wskazuje Marek Maleszewski: „Zapłodnienie pozaustrojowe dramatycznie zmieniło oblicze medycyny rozrodu. Techniki opracowane dla jej potrzeb okazały się być także bardzo przydatne w badaniach naukowych nad rozrodem i rozwojem człowieka oraz innych gatunków." Badacz ten dodaje, że „Od dnia, w którym prace w tej dziedzinie po raz pierwszy zakończyły się sukcesem, prawie 4 miliony dzieci urodziły się na świecie w wyniku stosowania zapłodnienia pozaustrojowego" (Maleszewski 2011, 5-15). Tym samym procedury diagnostyczne oraz terapeutyczne podejmowane na zarodku uznać można za zasadne z zapisem ustawy o działalności leczniczej. W art. 2 ust. 1 pkt 10 wspomnianego dokumentu zwrócono uwagę, że „świadczenie zdrowotne-działania służące zachowaniu, ratowaniu, przywracaniu lub poprawie zdrowia oraz inne działania medyczne wynikające z procesu leczenia lub przepisów odrębnych regulujących zasady ich wykonywania" (Ustawa 2011). Nie ulega zatem wątpliwości, że uznając innowacyjne podejście do płodności ukazane w wyżej opisanym materiałach prasowych, stwierdzić należy, iż nowatorskie techniki in vitro mogą zostać uznane za świadczenia zdrowotne odpowiadające aktualnemu stanowi wiedzy medycznej. Co więcej działania te kierowane są nie tylko w stronę kobiety doświadczającej niepłodności, ale ich adresatem jest także zarodek sztucznie powołany do życia. Jak wskazuje jednak prof. Kazimierz Szewczyk odnosząc się do zjawiska, jakim jest in vitro należy zaznaczyć, że jest to „nowoczesna metoda korekcji bezpłodności. Każda taka rozprzestrzeniająca się technologia niesie ze sobą jednak trudne wyzwania, bo może m.in. zaburzać tradycyjne relacje rodzinne“ (PAP 2012). Wspomniane przez łódzkiego bioetyka relacje rodzinne ulegają nie tylko zaburzeniu, ale także komplikacji w chwili, w której to podejmie się działania prokreacyjne $\mathrm{z}$ wykorzystaniem dwóch komórek jajowych oraz jednego plemnika. Jak wyżej wspomniano dziecko posiada wówczas część cech odziedziczonych po dwóch matkach i jednym ojcu. Aktualnie istnieje także możliwość, by w podobnej sytuacji zarodek został na etapie prenatalnym adoptowany przez inną kobietę. Do dwóch biologicznych 
matek dołączy kolejna kobieta, która np. w myśl przepisów polskiego Kodeksu Rodzinnego i Opiekuńczego, będzie matką dziecka. Podobne działania powodować mogą stan, w którym to pojawić się może zagrożenie dla zdrowia osoby, która przyszła na świat w drodze zapłodnienia metodą in vitro. Osobnik ten nie będzie miał możliwości uzyskania dokładnych informacji na temat swojego stanu zdrowia. W chwili, w której to np. jako osoba pełnoletnia będzie przekazywał informacje lekarzowi dotyczące jego życia, chorób dziedziczonych w rodzinie itd., w pewnym momencie dojdzie do „bariery” informacyjnej odnoszącej się do stanu zdrowia jego przodków. Tym samym podobne propozycje działań reprodukcyjnych prowadzić mogą do stanu, w którym to osoba leczona nie będzie miała pełnej możliwości realizacji prawa do uzyskania informacji o „stanie zdrowia ..., rozpoznaniu, proponowanych oraz możliwych metodach diagnostycznych i leczniczych, dających się przewidzieć następstwach ich zastosowania albo zaniechania, wynikach leczenia oraz rokowaniu" (Ustawa 2008).

\section{Dyskusja etyczna}

Analizując dyskusje dotyczące wprowadzenia na terenie Wielkiej Brytani możliwości wykorzystania mtDNA komórki jajowej dawczyni, w procedurze wspomaganego rozrodu określonej pary, dojść można do wniosku, iz stan ten posiada charakter dylematu moralnego. Jednostka chcąc wyrazić opinię na temat podobnych technik, w istocie postawiona zostaje w sytuacji, w której dokonać musi wyboru pomiędzy dwoma elementami, mogącymi posiadach zarówno pozytywne, jak i negatywne oblicze. Po pierwsze techniki manipulacji mtDNA niosą z sobą nadzieję na rozwiązanie społecznego problem, jakim są ciężkie, nieuleczalne zaburzenia mitochondrialne. Nie wiadomo jednak nadal jakie będą konsekwencje podobnych działań. Z drugiej perspektywy brak realizacji podobnych inicjatyw powodować może utrwalenie się bezpiecznego status quo, w którym nie pojawiają się obawy związane z wykorzystywaniem nieznanych technik, mogących wpływać na następne pokolenia. Podobny, w istocie brak działań sprawia jednak, iż nadal nie ma żadnych metod pomagających ominąć ww. zdrowotny problem. W tym miejscu pojawia się pytanie: Czy dylemat ten posiada charakter pośredni, czy też bezpośredni? Z perspektywy pracy embriologa, genetyka, biotechnologa itd. rozwiązanie powyższych wątpliwości wpływać może na pojawienie się określonego zagrożenia. Zapewne na rozstrzygnięcie dylematu u specjalisty wpływ mogą mieć zarówno przeżywane emocje, jak i osąd społeczny. Może dojść do sytuacji rozbieżności oraz konfliktu pomiędzy reakcją emocjonalną, a rozwiązaniem racjonalnym. Problem ten ma zatem dla ww. specjalistów postać bezpośrednią. Warto jednak pamiętać, że dla szeroko rozumianego społeczeństwa podobny dylemat posiada jedynie charakter pośredni. Jak zauważa Anna Górecka i Anna Szuster: „W przypadku drugiej grupy dylematów-pośrednich-osoba 
podejmująca decyzję jedynie «edytuje» zaistniałą sytuację. Dylematy pośrednie są ... mogą być więc rozwiązywane przy zaangażowaniu procesów poznawczych" (Górecka, Szuster 2011, 37).

Bez względu na powyższą wątpliwość, obserwując dynamiczny postęp jaki dokonał się w zakresie medycyny rozrodu należy wskazać, że medialne prezentowanie podobnych zagadnień powoduje, iż ich oceną zainteresowana będzie coraz większa rzesza odbiorców. Arnold Goldstein formułując założenia Treningu Wnioskowania Moralnego zwrócił uwagę, iż już sama próba odnalezienia rozwiązania powoduje wzrost poczucia „przyzwoitości, sprawiedliwości oraz uwzględniania praw innych osób”. Referowany autor w swoich działaniach, odnosił się do stadiów rozwoju moralnego Kohlberga, w którego ocenie dyskutowanie problemów etycznych powoduje osiągniecie wyższego poziomu rozwoju moralnego. Tym samym człowiek przechodzi od moralności prekonwencjonalnej (chce uniknąć kary, lub uzyskać konkretną korzyść), przez moralność konwencjonalną (chce mieć dobrą opinie, przyjmuje zdanie autorytetu), po moralność postkonwencjonalną (realizacja norm prawnych, odwołanie się do własnego, ukształtowanego sumienia). (Morawski 2003, 64- 66).

Chcąc odpowiedzieć na pytanie: Czy można stosować metody wspomaganego rozrodu $z$ wykorzystaniem modyfikacji mtDNA komórki jajowej?, z cała pewnością odwołać się można do podstawowej normy deontycznej, brzmiącej: czyń dobro, zła unikaj (Kodeks 2006, 7). Goldstein wskazując na możliwości wewnętrznego rozstrzygnięcia danego problemu, sugeruje odwołanie się do pytania o intencje podejmowanych działań, doświadczane $\mathrm{z}$ nimi uczucia oraz o spodziewane konsekwencje danego postępowania (Morawski 2003, 63). Analiza wypowiedzi naukowców popierających omawiane metody reprodukcyjne wskazuje, iz podstawowym celem ich wprowadzenia nie jest chęć manipulacji ludzkim genomem, ale dążenie do opanowania techniki, która pozwoli na narodziny zdrowego dziecka, nie obarczonego określonymi, dziedzicznymi zaburzeniami. Podkreślono, że jest to $\mathrm{w}$ istocie forma terapii na najwcześniejszym, jeszcze komórkowym etapie rozwoju. Oceniając zatem konsekwencje podobnego działania należałoby wskazać, iż będą miały one pozytywny charakter. Dzięki nim kobieta będzie mogła urodzić w pełni zdrowe dziecko. Proponowana ocenia działań biotechnologicznych, natrafia $\mathrm{w}$ tym miejscu na istotny problem. W opinii części genetyków legalizacja omawianych technik, następuje za szybko. $\mathrm{W}$ istocie bowiem nie wiadomo jakie będą konsekwencje zastosowania transferu jądra komórkowego, do innej komórki rozrodczej. Jak dostrzega prof. Monika Ołdak, aktualnie nie wiemy, jak rozwijać się będą w przyszłości dzieci, które na etapie zarodkowym przeszły podobne laboratoryjne procedury (Dziekoński \& Grzymek 2015). Podobne obawy pojawiły się na terenie USA. Dr Ricki Lewis zwrócił uwagę, iż nadal badacze nie wiedzą, jak jądro komórkowe będzie rozwijać się w obcym biologicznie 
otoczeniu. Ponadto wskazano, że pojawiają się przypuszczenia, zgodnie z którym za część schorzeń o podłożu mitochondrialnym odpowiada nie tylko mitochondrium komórki, ale również jej jądro (Ricki 2015). Podobne stwierdzenia naukowców posiadają kluczowe znaczenie dla oceny etycznej omawianych innowacyjnych działań. Wiemy bowiem, jak wygląda określona czynność biologiczna. Posiadamy przypuszczenie, iż intencja badaczy jest w pełni słuszna. Nie wiemy jednak, jakie konsekwencje medyczne, biologiczne oraz społeczne pojawią się po wprowadzeniu analizowanych technik. Brak podobnej wiedzy powoduje, iż jako negatywne należy uznać podejmowanie podobnych działań, które de facto przed wprowadzeniem nie zostały w pełni poznane przez ich promotorów.

\section{Próba konkluzji}

Przechodząc do podsumowania wyżej zaproponowanych analiza oraz refleksji należy zaznaczyć, że jakakolwiek dyskusja na temat sztucznego powołania do istnienia dziecka $\mathrm{z}$ obcym mtDNA nie ma uzasadnienia $\mathrm{w}$ chwili, w której to uznamy, iż metoda In vitro nie zasługuje na akceptację z racji etycznych (Leźnicki \& Lewandowska 2013, 212), jak wskazano powyżej ocean moralna procedury wspomaganego rozrodu posiada charakter niejednoznaczny. Działania te nadal stanowią w istocie obszar niepoznany dla embriologów: nie wiadomo w pełni czemu skuteczność terapii jest nadal niska, nie ma pełnej wiedzy na temat uwarunkowania powstawania wad rozwojowych embrionu, ponadto sprzeciw licznych środowisk wzbudza praktyka poddawania zarodków procedurze kriokonserwacji (Zob. Szostek 2009, 19). Faktem jest jednak, iż na mapie świata brak jest państw, które wprowadziły by zakaz stosowania podobnej metody wspomaganego rozrodu. Podobnie w Polsce pomimo całkowicie uzasadnionych wątpliwości medycznych oraz etycznych, nie jest możliwe wprowadzenie prawnego zakazu podejmowania podobnych działań, akceptowanych na poziomie pomiędzy 60\% (2008) a 77\% (2009) (CBOS 2010, 3).

Informacje z Wielkiej Brytanii zmuszają do zastanowienia się, w jaką stronę idzie dzisiaj medycyna reprodukcyjna. Z jednej strony podejmowane są badania mające na celu dokładne poznanie procesu zapłodnienia. Odkrycie występowania mitochondrialnych przyczyn poszczególnych zaburzeń z całą pewnością uznać należy za wielki sukces. Embriolodzy oraz ginekolodzy posiadają tym samym nowy obszar badań, który pozwoli nie tylko dokładnie diagnozować, ale również leczyć choroby powstałe w wyniku podobnych genetycznych zaburzeń

W tym miejscu warto dodać jednak, że sama procedura in vitro wiąże się z pojawieniem się większego niebezpieczeństwa występowania ww. typu schorzeń. Badacze wskazują, iż przyczyny powyższego zjawiska mogą mieć różny charakter. Z jednej strony zwraca się uwagę na starszy wiek kobiet 
biorących udział $\mathrm{w}$ procedurze. $\mathrm{Z}$ drugiej jednak perspektywy naukowcy analizujący zjawiska epigenetyczne sugerują, iż najniebezpieczniejsza w procedurze jest sama technika zapłodnienia polegająca na „wpychaniu” plemnika do komórki jajowej (Losz 2013, 6-7). Analizy neonatologiczne oraz genetyczne sugerują, że w procedurze zapłodnienia pozaustrojowego istnieje zwiększone ryzyko wystąpienia u dziecka zespołów Beckwitha-Wiedemanna oraz Angelmana (Piątek \& Koziarska-Rościszewska 2013, 17). Warto także dostrzec zjawisko, które opisał prof. Maciej Krupisz. Zdaniem badacza „chłopcy poczęci metodą in vitro, z powodu słabej jakości nasienia ojca (zwłaszcza jeśli przyczyną są wady genetyczne związane z chromosomem Y) będą mieli w przyszłości te same kłopoty" (Bielicka 2012). Być może zatem powstanie mikrochirurgicznych technik pozwoli na eliminację podobnych niebezpieczeństw w trakcie stosowania omawianej metody. Szanując głos przeciwników zapłodnienia „na szkle” nie można w tym miejscu nie zwrócić uwagi, iż działania takie mogą mieć szczególne znaczenie w przypadku adopcji prenatalnej. Rozwój diagnostyki oraz chirurgii preimplantacyjnej powodować może, iż znikną obawy typu: Czy adoptowany zarodek poddać badaniu? A co będzie gdy w badaniu dostrzeżone zostaną wady zarodka? Dzięki technikom promowanym obecnie w Anglii pojawić się może zapewne technika leczenia zarodka. Czy dotyczy to jednak wszystkich zarodków?

$\mathrm{W}$ laboratoriach procedura in vitro $\mathrm{w}$ postaci modyfikacji mtDNA testowana jest w oparciu o wykorzystanie dwóch technik. W pierwszej z nich zamiana mitochondrialnego DNA (a w zasadzie jądra komórki jajowej) nasteruje przed zapłodnieniem. Podobne działania przeprowadzał Shukhrat Mitalipov z Narodowego Centrum Badań nad Naczelnymi stanu Oregon w Beaverton (USA). Pobrał on 65 komórek jajowych od kobiet biorących udział w eksperymencie. Wyniki badań nie były jednak w tym przypadku obiecujące. Okazało się, ze tylko 48\% zarodków rozwijało się prawidłowo. Jak informuje Margit Kossobudzka:

Podobną metodę, ale polegająca na zamianie jąder komórkowych
już po zapłodnieniu komórki jajowej (gdy powstają tzw.
przedjądrza) zaproponowali w 2008 roku naukowcy z
uniwersytetu Newcastle. Kierująca wtedy pracami prof. Mary
Herbert uważa, że takie rozwiązanie jest lepsze, bo pozwala
komórce jajowej normalnie się zachowywać podczas
zapłodnienia. To powoduje, że więcej zarodków zdrowo się
rozwija (Kossobudzka 2012).

Podobne działania ukazują $\mathrm{w}$ istocie trudny do rozstrzygnięcia problem oceny innowacyjnych technik wspomaganego rozrodu. Z jednej bowiem strony działania takie mają pozytywny cel niesienia pomocy istotom znajdującym się na najwcześniejszym etapie rozwoju. Korzystając z wiedzy genetycznej ludzie starają się zmienić określone struktury, które prawdopodobnie odpowiadają za powstawanie części zaburzeń na dalszym etapie życia człowieka. Stąd też 
mamy w tym miejscu do czynienia z terapią, która jest następstwem diagnozy. Argument przeciwników in vitro krytykujących niszczenie zarodków, u których wykryto wady traci $\mathrm{w}$ tym miejscu na sile. Embriolodzy bowiem podejmują działania, które mają na celu poprawę zdrowia przyszłego embrionu. Staje się on w tym miejscu pacjentem, który korzysta z świadczeń zdrowotnych oferowanych przez najnowszą medycynę. Z drugiej jednak perspektywy podejmowanie podobnych interwencji wiąże się $z$ występowaniem konsekwencji $w$ istocie trudnych do przewidzenia. Badacze sami wskazują, iż wiele obszarów dotyczących zapłodnienia pozostaje nadal niepoznanych.

Warto jednak zwrócić $\mathrm{w}$ tym miejscu uwagę, że w licznych wypowiedziach ekspertów podejmujących trud poznania fenomenu poczęcia co chwila napotykaliśmy zwroty typu: „produkowali zdrowe małpy”, czy też „Naukowcy z Oregonu wyprodukowali około tuzina wczesnych ludzkich embrionów i uważają, że technika ta jest wysoce efektywna...". W tym miejscu pojawia się obawa , iż działania terapeutyczne podejmowane wobec zarodków będą miały w istocie charakter produkcyjny. Człowiek będzie reprodukowany. Czy zatem lekarze, genetycy i badacze będą potrafili oddzielić leczenie zarodka od tworzenia człowieka na „konkretny obraz oraz podobieństwo”? Dokonując podsumowania powyższych analiz oraz refleksji należy w pełni zgodzić się z uzasadnionymi obawami dotyczącymi wprowadzania technik, takich jak transfer mtDNA pomiędzy żeńskimi komórkami rozrodczymi. Z całą pewnością podobne propozycje są efektem dynamicznego postępu nauk biomedycznych. Ów dynamizm doprowadził jednak do tego, iż zalegalizowana została metoda, która stanowi nadal tajemnice dla samych jej twórców. Każde dziecko poczęte w wyniku jej zastosowania, będzie w zasadzie elementem eksperymentu badawczego. Naukowcy będą przyglądać się jego rozwojowi fizycznemu oraz psychospołecznemu. Warto w tym miejscu przypomnieć jednak, iż eksperymenty medyczne mogą być prowadzone na ludziach jedynie za ich zgodą. W tym miejscu zgodę wyrażają rodzice oraz dawczyni komórki jajowej. Jej konsekwencje ponosić będzie jednak zupełnie inne osoby.

\section{Literatura}

Ambroziak, A. 2013. „Dziecko trojga rodziców”. Nasz Dziennik. URL: http://www.naszdziennik.pl/polska-kraj/60267,dziecko-trojgarodzicow.html?d=1.

Bielicka, M. 2012. „In vitro to nie tylko szczęście, ale i ryzyko. Wywiad z prof. Maciejem Krupiszem". Gazeta Wyborcza. URL: http://www.dlazycia.info/index.php?option=com_content\&view= 
article\&id=1601:in-vitro-to-nie-tylko-szczcie-ale-i-

ryzyko\&catid=11: prolifeinternetkategoria\&Itemid=162.

Biomedical. 2012. „Zapłodnienie in vitro od trzech osób. Embriony od 2 kobiet i jednego mężczyzny stworzone w laboratorium". Serwis Biomedical. URL: http://www.biomedical.pl/aktualnosci/zaplodnienie-in-vitro-odtrzech-osob-embriony-od-2-kobiet-i-jednego-mezczyzny-stworzonew-laboratorium-8494.html.

Bruchwald, A. 2013. „Jedno dziecko, trzech rodziców - rząd popiera eksperymenty!". Prawy.pl. URL: http://www.prawy.pl/rodzina/3414jedno-dziecko-trzech-rodzicow-rzad-popiera-eksperymenty.

Czarnecki, M. 2013. „Brytyjczycy chcą pozwolić na in vitro z materiałem genetycznym od trzech osób”. Gazeta Wyborcza. URL: http://wyborcza.pl/1,76842,14187926,Brytyjczycy_chca_pozwol ic_na_in_vitro_z_materialem.html\#ixzz3Pqm7VgIT.

Dokument. 2013. "Mitochondria Replacement Consultation: Advice to Government." Human Fertilisation and Embryology Authority: London.

Dziekoński, J., Grzymek, J. 2015. „Gra w DNA”. Medycyna Praktyczna. URL: http://www.mp.pl/pediatria/wywiady/show.html?id=116173\&u tm_source=strona_glowna\&utm_medium $=M P \& u t m \_c o n t e n t=s l i d e r$.

Goban-Klas, T. 1984. „Analiza zawartości przekazów masowych”, w: J. Wasilewski (red. naukowa). Wybrane zagadnienia teoretycznometodologiczne badań socjologicznych. Kraków: Wydawnictwo Uniwersytetu Jagiellońskiego: 294-301.

Górecka, A. \& Szuster, A. 2011. „O pozornej nieuchronności autowaloryzacji w obliczu dylematów moralnych. Rola dostępności standardów poza-Ja i przeciążenia poznawczego". Psychologia społeczna 1(6): 34-48.

Human Life International. 2013. „Wielka Brytania: Jeden embrion, troje rodziców - nowa technika in vitro". URL: http://www.hli.org.pl/drupal/pl/node/7834.

Jaros, P. 2013. „Rzecznik Praw Dziecka w Polsce”. Warszawa: Biuro Rzecznika Praw Dziecka.

Kossobudzka, M. 2012. „Będzie pierwsze dziecko z trójki rodziców?” Gazeta Wyborcza. URL: http://wyborcza.pl/1,75400,12755957, Bedzie_pierwsze_dziecko_z_trojki_rodzicow_html.

Polska Agencja Prasowa. 2012. „Nagroda Nobla z medycyny za dziecko z probówki". Nauka w Polsce. URL: http://www.naukawpolsce.pap.pl/ aktualnosci/news,376345,nagroda-nobla-z-medycyny-za-dziecko-zprobowki.html.

Kalb, C. 2003. „Treating the Tiniest Patients.” Newsweek, June 9: 48- 51.

Kobisz, T. 2013. „Dziecko trojga genetycznych rodziców - prawdopodobnie już za rok". Medexpress.pl: 1-2. 
Kmieciak, B. 2012. „Spotkanie: Etyka we współczesnej biotechnologii i biobiznesie: relacja i refleksja". Biuletyn Bioetyczny 1: 16- 21.

———. 2012. „In vitro: współczesny areopag. Wywiad z ks. prof. Janem Wolskim". Biuletyn Bioetyczny 2: 4-13.

Konwencja, 1989. „Konwencja o prawach dziecka przyjęta przez Zgromadzenie Ogólne Narodów Zjednoczonych dn. 20 listopada 1989 r." Dz. U. z dnia 23 grudnia $1991 \mathrm{r}$.

Kodeks Etyki Diagnosty Laboratoryjnego. 2006. „Załącznik do uchwały nr 4/2006 Nadzwyczajnego Krajowego Zjazdu Diagnostów Laboratoryjnych z dnia 13 stycznia 2006 r."

Losz, K. 2013. „In vitro z wadami: rozmowa z prof. Aldoną Midro”. Nasz Dziennik 166: 6-7.

Lisowska-Magdziarz, M. 2006. „Dyskurs - semiotyka - wspólnota interpretacyjna. $\mathrm{W}$ stronę modelu zintegrowanego instrumentarium badan nad zawartością mediów". Global Media Journal-Polish Edition 1: 1-11.

Leźnicki, M. \& Lewandowska, A. 2013. „Biomedykalizacja a genetyczne udoskonalanie człowieka w kontekście analiz bioetycznych". Acta Universitatis Lodziensis. Folia Sociologica. 45: 113-129.

Maleszewski, M. 2011. „Zapłodnienie i zapłodnienie in vitro. Nagroda Nobla z biologii lub medycyny 2012". Kosmos 1- 2(60): 5-16.

Ministerstwo Zdrowia. 2009. Program kompleksowej diagnostyki i terapii wewnątrzmacicznej $w$ profilaktyce następstw $i$ powikłań wad rozwojowych i chorób płodu - jako element poprawy stanu zdrowia płodów i noworodków na lata 2009-2013 - część A i B. Warszawa: Ministerstwo Zdrowia.

Ministerstwo Zdrowia. 2013. Program leczenia niepłodności metodq zapłodnienia pozaustrojowego na lata 2013-2016. Warszawa: Ministerstwo Zdrowia.

Morawski, J. 2003. Trening Zastępowania Agresji (ART). Warszawa: Instytut Amity..

Ordo Iuris, 2013a. „Protest przeciwko tworzeniu dzieci od trójki rodziców”. Fronda.pl URL: http://www.fronda.pl/a/protest-przeciwko-tworzeniudzieci-od-trojki-rodzicow,32150.html.

Ordo Iuris. 2013b. „Tworzenie dzieci trójki rodziców narusza godność człowieka i prawo międzynarodowe". Serwis Ordo Iuris. URL: $\quad$ http://www.ordoiuris.pl/tworzenie-dzieci-trojki-rodzicownarusza-godnosc-czlowieka-i-prawo-miedzynarodowe,3343, analizaprawna.html.

Ordo Iuris. 2015. „O nas: Instytut na rzecz Kultury Prawnej Ordo Iuris”. Serwis Ordo Iuris. URL: http://www.ordoiuris.pl/centrum,3179,c.html. 
PAN. 2012. Stanowisko Komitetu Bioetyki przy Prezydium PAN nr 2/2012 z dnia 8 czerwca 2012 r. w sprawie preimplantacyjnej diagnostyki genetycznej. Warszawa: PAN.

Piątek, A. \& Koziarska-Rościszewska, M. 2013. „Wpływ in vitro i innych technik wspomaganego rozrodu na występowanie zaburzeń postnatalnych". Nowa Pediatria 1: 10-18.

Pieniążek, A. \& Stefaniuk, M. 2003. Socjologia prawa: zarys wykładu. Kraków: Wydawnictwo Zakamycze.

Portal Pch24, 2013. „Rząd Wielkiej Brytanii poparł nową metodę produkcji dzieci z probówki: DNA od trzech rodziców". Polonia Christiana. URL: http://www.pch24.pl/rzad-wielkiej-brytanii-poparl-nowa-metodeprodukcji-dzieci-z-probowki--dna-od-trzech-rodzicow,16016,i.html.

Raport, 2010. Etyczne aspekty zapłodnienia in vitro. Warszawa: CBOS.

Ricki, L. 2015. „Mitochondrial Manipulation Technology Unlikely in United States Anytime Soon". Medscape Ob-Gyn. URL: http://www.medscape.com/viewarticle/840479.

Stępniewska, K. 2012. „Trójka rodziców biologicznych? To możliwe, a niedługo może też legalne!". Metro. http://metro.gazeta.pl/ Lifestyle/1,127257,12512383,Trojka_rodzicow_biologicznych_To_mo zliwe_a_niedlugo.html.

Szymanowski, L. 2013. „Dalszy krok po in vitro. Zalegalizują dzieci z trójki rodziców?". Nowy Ekran 6: 1-2.

Szczepaniak, K. 2012. „Zastosowanie analizy treści w badaniach artykułów prasowych: refleksje metodologiczne". Acta Universitatis Lodziensis. Folia Sociologica 47: 83-101.

Szacka, B. 2003. Wstęp do socjologii. Warszawa: Oficyna Naukowa.

Szostek, A. 2009. „Etyczne aspekty zapłodnienia in vitro”. Chrześcijaństwo Świat - Polityka 1: 5-13.

Tachibana, M., Amato, P., Sparman, M. et al. 2011. „Human Embryonic Stem Cells Derived by Somatic Cell Nuclear Transfer." Reproductive BioMedicine Online 22: 200-207.

Ustawa z dnia 25 lutego 1964 r. Kodeks rodzinny i opiekuńczy (Dz. U. nr 9 poz. 59 z późn . zm. )

Ustawa z dnia 15 kwietnia 2011 r. o działalności leczniczej (Dz.U. 2013.217).

Ustawa z dnia 6 listopada 2008 r. o prawach pacjenta i Rzeczniku Praw Pacjenta. (Dz. U. Nr 111, poz. 535 z późn. zm.)

Wojewoda, M. Zabłocki, K., \& Szczepanowska, J. 2011. „Choroby spowodowane mutacjami w mitochondrialnym DNA". Postępy Biochemii 57: 222-229. 
Błażej Kmieciak (Łódź)

\title{
W stronę chirurgii zarodka: Socjoprawne aspekty innowacyjnych technik wspomaganego rozrodu
}

\section{Toward Embryo Surgery: the Socio-Legal Aspects of the Innovative Techniques for Assisted Reproduction}

\begin{abstract}
Abstrakt. Na początku 2015r, w Wielkiej Brytanii zezwolono na stosowanie nowej techniki wykorzystywanej $\mathrm{w}$ procedurze wspomaganego rozrodu in vitro. Wprowadzono możliwość zastosowania trzech komórek rozrodczych; jednej pochodzącej od mężczyzny oraz dwóch pobranych od kobiet.(dwóch różnych kobiet). Działania te związane są $\mathrm{z}$ szansą wymiany jądra komórkowego, w którym dostrzeżono istotne anomalie genetyczneuszkodzenie mitochondrium komórki, czyli mtDNA. Liczni badawczo zwracali uwagę, że podobna możliwość zmniejszy prawdopodobieństwo pojawienia się u dziecka poważnych chorób, niejednokrotnie prowadzących do jego śmierci w młodym wieku. Część bioetyków uznała jednak, że wspomniane działania doprowadzą do istotnych szkód społecznych, prawnych oraz medycznych. Podkreślano, że poczęte dziecko, będzie miało trójkę rodziców: jednego tatę i dwie matki. Dodawano ponadto, że omawiane interwencje w ludzki genom, są nieuprawnioną manipulacją.

Czy mamy zatem do czynienia z postępem medycyny? Czy modyfikacje mtDNA określić można mianem "chirurgią zarodka"? Czy pojawią się techniki leczenia zarodka? Czy jednak wiemy, jakie pozytywne i negatywne konsekwencje spowoduje modyfikacja mtDNA? Czy nie jest to zatem (nieuprawniony) eksperyment?
\end{abstract}

Słowa kluczowe. mitochondrium. DNA, zarodek, zapłodnienie pozaustrojowe, bioetyka, prawa człowieka

Abstract. At the beginning of 2015, the UK permitted to use the new technology used in the procedure of the in vitro fertilization. It was tntroduced the possibility of using the three germ cells; one derived from a man and two collected from women. (two different women). These actions are associated with the chance to exchange cell nucleus, where recognizes the 
significant genetic abnormalities: damage to the mitochondria of the cell, (mtDNA). Many researchers have pointed out that a similar opportunity reduce probability of occurrence of child's serious illness, often leading to his death at a young age. Part of bioethicists considered, however, that these actions will lead to significant social, legal and medical harm. It was emphasized that the child will have three biological parents: one father and two mothers. Also added that these interventions in the human genome, are in effect fraudulent manipulation.

Are we dealing with the progress of medicine? Is mtDNA modifications might be termed "embryo surgery"? Will there be an embryo treatment techniques? Do we know what positive and negative consequences will result in modification of mtDNA? Perhaps it is therefore (unauthorized) experiment?

Keywords: Mitochondrion. DNA, embryo, in vitro fertilization, bioethics, human rights

Ethics in Progress (ISSN 2084-9257). Vol. 6 (2015). No. 1, pp. 141-153.

doi:10.14746/eip.2015.1.11 